\title{
Recepção transmídia: perspectivas teórico- metodológicas e audiências de ficção televisiva online
}

\author{
Maria Immacolata Vassallo de Lopes' \\ Fernanda Castilho' \\ I - ECA-USP \\ São Paulo (SP), Brasil
}

Resumo: A proposta deste artigo é discutir o trabalho teórico e metodológico desenvolvido pelo Observatório Ibero-Americano de Ficção Televisiva (Obitel) sobre o tema da recepção transmídia, focando na progressão de suas conceituações e estratégias metodológicas. Toma-se como corpus de análise as pesquisas realizadas entre 2010 e 2015, na medida em que comprovaram que o engajamento das audiências online está crescendo rapidamente, legitimando assim um objeto de estudo emergente. Como resultado, demonstram-se as contribuições e atualizações à pesquisa de recepção no Brasil e na América Latina feitas pelo Obitel.

Palavras-chave: ficção televisiva; recepção transmídia; protocolos metodológicos; Obitel.

Abstract: Transmedia reception: theoretical-methodological perspectives and online television fiction audiences - The purpose of this article is to discuss the theoretical and methodological work developed by the Ibero-American Television Fiction Observatory (Obitel) on the theme of transmedia reception, focusing on the progression of concepts and methodological strategies. The corpus of research conducted between 2010 and 2015 is justified as it has shown that the engagement of online audiences is growing rapidly, and therefore legitimize an emerging study object. As a result, the contributions and improvement to the reception research in Brazil and Latin America by Obitel are demonstrated.

Keywords: television fiction; transmedia reception; methodological protocols; Obitel. 


\section{Introdução: narrativas em convergência na produção e na recepção de ficção televisiva}

A proposta deste artigo é revisitar o trabalho teórico e metodológico desenvolvido no âmbito do Observatório Ibero-Americano de Ficção Televisiva (Obitel) a respeito do tema da recepção transmídia nos anuários Obitel publicados de 2010 a 2015, fazendo a discussão das conceituações, estratégias metodológicas e análises aí geradas. Julgamos pertinente revisitar os estudos feitos dentro de um quadro de mudanças extremas, tanto em termos de preservação da memória desse tipo de estudos, que tem a particularidade de trabalhar com a própria volatilidade encarnada em seus objetos, quanto, e principalmente, apontar as contribuições à atualização das pesquisas de recepção feitas pelo Obitel.

As pesquisas sobre o assunto tiveram como ponto de partida o conceito de convergência midiática, encontrado ao longo de trabalhos de Jenkins $(2004$; 2008) a fim elaborarmos teorizações fundadas em evidências empíricas no âmbito da produção e da recepção de telenovela (LOPES, 2003). Jenkins (2008, p. 29) define cultura da convergência como o momento que vivemos, em que velhas e novas mídia colidem, mídias empresariais e alternativas se cruzam, e poderes do produtor e do consumidor interagem de formas imprevisíveis com seus diferentes interesses.

Observamos nesse cenário diferentes lógicas de produção e de recepção de conteúdos que se expressam através de relações cada vez mais complexas entre as mídias empresariais, de cima para baixo, simultaneamente à construção de uma cultura participativa com relações de baixo para cima e dentro de um cenário de mudanças aceleradas. Vemos a convergência como processo e não como fim, assim como não limitada a processos tecnológicos que implicam a mudança cultural.

Castells (2009) fala em audiências criativas, que atuam colaborativamente para desenvolver conteúdos possíveis de funcionar em diversas mídias. Esse modo de realização, crescentemente adotado nas indústrias de mídia, passa a ser chamado de transmedia storytelling ou narrativa transmídia. Hoje, as informações que estão na rede se desprendem do sujeito narrador para se tornar um hipertexto. As narrativas online e os hipertextos estão apagando na sociedade a ideia de autoria narradora, pois a tessitura da storytelling se produz em semiose infinita. O fato que gera uma storytelling se desdobra em outras versões intertextuais e multimídias formando uma rede de infinitas interpretações. Esse processo cria a transmedia storytelling, na qual uma mesma narrativa que, em geral, ganhou notoriedade, passa de uma mídia a outra, em diferentes suportes e diferentes linguagens, com uma rapidez impressionante. .

Anotamos aqui a definição que já se tornou clássica de transmedia storytelling:

uma história que se desdobra através de múltiplas plataformas de mídia, cada qual com um novo texto, fazendo uma colaboração distinta e valiosa para 
o todo. Na forma ideal de narrativa transmidiática, cada meio faz o que faz de melhor, a fim de que uma história possa ser introduzida em um filme, ser expandida pela televisão, romances e quadrinhos; seu universo possa ser explorado em games ou experimentado como atração de um parque de diversões. (JENKINS, 2008, p. 135)

\section{Narrativas transmídia}

Observando os processos de desenvolvimento das narrativas transmídia, podemos, em princípio, identificar dois momentos de trânsito entre a movimentação de conteúdo e os demais fluxos de sentidos em rede: antes e após a entrada da participação do receptor (por meio dos processos que incentivam a interatividade). Por isso, tentaremos marcar, com as observações presentes neste texto, essa trajetória que pode ser identificada desde o folhetim até os dias atuais, de modo que a narrativa transmídia - como a vemos hoje - esteja sempre imbricada em seu tempo, permitindo que as narrativas trilhem caminhos diferentes e se reconstruam por dentre eles de maneiras sempre novas.

São vários os exemplos de trânsito observados entre diferentes mídias, com um envolvimento contínuo entre livro, rádio, TV, cinema e outros meios. Esse cenário alcançou tamanha mobilidade que há múltiplas telas nos acompanhando continuamente. Elas permitem o surgimento de uma nova ambiência, um sensório envolvedor, que está em todo lugar a todo tempo.

Esse caráter complementa as novas construções de identidade, novos sensórios (no sentido apresentado por Benjamin), que se formam a partir dessa realidade modificada tecnologicamente e produzem, por meio de também novas mediações digitais, outros meios de ser e estar na sociedade, conforme Martín-Barbero:

\footnotetext{
Essa reconfiguração encontra seu mais decisivo cenário na formação de um novo sensorium: frente à dispersão e à imagem múltipla que, segundo W. Benjamin, conectavam "as modificações do aparelho perceptivo do transeunte no tráfego da grande cidade", do tempo de Baudelaire, com a experiência do espectador de cinema, os dispositivos que agora conectam a estrutura comunicativa da televisão com as chaves que ordenam a nova cidade são outros: a fragmentação e o fluxo (1998, p. 64).
}

As mídias sociais têm ingressado profundamente nos mecanismos da vida cotidiana, afetando a comunicação interpessoal, as interações informais e as estruturas institucionais, modificando condições e regras de relacionamento social (LÉVY, 1993).

A mediação da tecnicidade de Martín-Barbero (2001) nos ajuda a compreender os processos envolvidos nesse mundo híbrido, não mais restrito apenas às classes socioeconômicas privilegiadas, especialmente no que se refere à alta capacidade 
de inovação e criação das audiências observada ao longo das análises realizadas pelo Obitel. Sobretudo considerando que essa mediação não se refere apenas aos aparatos tecnológicos, mas a uma tecnicidade cognitiva e criativa (SCOLARI, 2004). Aponta-se para o surgimento de um novo estatuto social da técnica no qual se enquadra a criação de novas narrativas, acima de tudo de forma mais coletiva, em rede. A conexão em rede levou intelectuais a repensar o entendimento dos processos que envolvem a comunicação, até mesmo Martín-Barbero (2004).

A conexão entre forças econômicas e criatividade das audiências passou a movimentar o mercado das indústrias criativas. Os nativos digitais (PRENSKY, 2001) adquirem capacidades técnicas e criativas que chamam atenção dos produtores, assim como o desenvolvimento de comunidades de fãs com interesses em comum. Constituem redes que facilitam processos de envolvimento (MELUCCI, 1994), pois nelas os participantes interagem e negociam sentidos por meio de trocas simbólicas. Lévy (2003) denomina esse conjunto de inteligências reunidas de inteligência coletiva, uma prática de comunicação interativa, recíproca, comunitária e intercomunitária, com mobilização efetiva de competências e mediada pela internet. A conclusão a que chega Martín-Barbero (2004, p.184) é que a questão das novas tecnologias de comunicação nos obriga, assim, a analisar os diferentes registros a partir dos quais elas estão remodelando as identidades culturais.

É possível dizer que talvez nunca tenhamos acompanhado tamanho fluxo de conteúdos que perpassam as diversas mídias e, reinventando-se a partir de cada uma delas, tornem-se um produto passível de trânsito em todas elas como observamos neste momento. Ampliam-se, desse modo, a fluidez e a possibilidade de caminhos de múltiplas direções.

Segundo Fechine (2009), a ampliação desses fluxos se apoia nas facilidades propiciadas pela digitalização das informações, que, por sua vez, permitem que as experiências transmídia se baseiem na reiteração e na pervasividade de conteúdos. É a partir daí que os variados suportes são chamados a explorar o mesmo percurso narrativo de base, explorando seus programas paralelos e expandindo seus personagens.

Inserida no cenário de convergência digital e de globalização, a indústria midiática, da qual a TV é um dos braços mais importantes, orienta-se cada vez mais pelo surgimento de formas culturais que não estão mais baseadas em um medium, mas em um conjunto, sendo assim transferíveis de uma plataforma para outra. Esse fenômeno desencadeou a produção de narrativas transmídia que nascem com a intenção de se espalharem pelas diversas mídias. Ocorre a migração de dispositivos midiáticos em direção a outras ferramentas ou meios de comunicação, como personagens de livros que aparecem em filmes e jogos, ou programas de televisão adaptados para a internet. Essa lógica de produção e de consumo de narrativas envolve a criação de novos espaços de comunicação e de socialização. 


\section{Transmídia não é um fenômeno totalmente novo}

A migração nestes espaços não é completamente nova e não surge com os meios virtuais, é apenas acelerada por eles. Esse fenômeno adquiriu novos contornos ao longo do tempo, pois os próprios núcleos de produção de ficção televisiva desenvolvem conteúdos que ultrapassam a televisão e encontram espaço e audiência em outras mídias caracterizadas pela mobilidade, portabilidade e interatividade. Para Lévy (1999), a interatividade é caracterizada pelo estreitamento da relação entre emissores e receptores da mensagem, relação marcada atualmente pela criatividade, reapropriação e recombinação dos conteúdos.

Algumas análises do Obitel, como veremos a seguir, utilizaram como base os diferentes tipos de interatividade apontados por Lévy'. Esse autor foi pioneiro na definição dos diferentes níveis de interação e participação no âmbito da comunicação mediada por computador (atualmente, mediada por dispositivos móveis ligados à internet), por isso sua contribuição ao campo dos estudos das mídias digitais se tornou muito importante. Também no Brasil se refletiu acerca desse conceito. Primo (2007), uma das fontes de nossas pesquisas, definiu dois tipos de interatividade: a reativa (conforme as opções do produtor) e a mútua (criação mais livre do receptor). García Canclini (2008, p.33) indica que a interatividade possibilitada pela internet desterritorializa os conteúdos e, "devido à convergência digital desses meios, são reorganizados os modos de acesso aos bens culturais e às formas de comunicação".

O ponto central dessa nova cultura de consumo da ficção televisiva é precisamente a participação das audiências nos processos criativos, como indicam os exemplos empíricos que serão apontados neste trabalho. E os incentivos à participação são mútuos, ou seja, envolvem produtores e audiências. As novas gerações estão habituadas a participar do processo de criação dos personagens e suas histórias, portanto, esperam que essa relação continue (ibidem, 2008, p.33).

Segundo Fechine (2009), o apelo à familiaridade do público com sua produção parece estar na base de uma transmídia à brasileira desenvolvida pela Globo, explorando durante bastante tempo a circulação dos mesmos universos ficcionais entre a televisão e o cinema, assim como seus desdobramentos (DVDs e CDs com trilhas sonoras). Essa familiaridade dá-se com o reconhecimento de determinados mundos ficcionais difundidos pela TV, a partir de todos os elementos implicados na sua constituição, como as figuras mais frequentes, os papéis narrativos recorrentes, os atores que os representam, bem como o estilo de direção e de montagem. Observar essas audiências ativas e participativas

1 A saber: mensagem linear não-alterável em tempo real (não há como modificar ou interferir no conteúdo dado pelo emissor); interrupção e reorientação do fluxo informacional em tempo real (existe a possibilidade de resposta, ou trânsito de conteúdo entre emissor e receptor); implicação do participante na mensagem (o receptor alcança também a condição de emissor). 
da ficção televisiva, especialmente as atividades dos fãs, tem sido um dos principais objetivos da nossa rede de pesquisa.

\section{A recepção transmídia nos Anuários Obitel}

As pesquisas realizadas pelo Obitel propõem identificar e analisar em cada um dos 12 países participantes ${ }^{2}$ e 10 grupos nacionais ${ }^{3}$ exemplos de narrativas que nascem com a intenção de difundir-se através de diversos meios (cinema, rádio, celular, internet, DVD, CD, videogames); diversas plataformas (televisão aberta, cabo, satélite, VoD) e formatos (telenovela, série, minissérie, película, telefilme, soap opera, etc). Esse mapeamento é realizado desde 2009, sobretudo com foco no conceito de recepção transmídia, a partir da noção trabalhada pelos grupos de pesquisa nacionais e internacionais. É importante notar que se trata de um termo utilizado desde a criação da seção homônima no Anuário Obitel, em 2011, na qual são analisadas a oferta de narrativas televisivas difundidas em diferentes plataformas digitais e a participação das audiências nesses meios no contexto ibero-americano. O fundamento teórico que acompanha tais pesquisas tem origem fundamentalmente em bibliografia anglo-saxônica (EVANS, 2011; BOOTH, 2010; SANDVOSS, 2005). No entanto, o desenvolvimento das pesquisas realizadas na América Latina, especialmente no Brasil ${ }^{4}$, está atribuindo contornos nacionais em termos de apropriação do conceito no contexto dos fãs brasileiros. É dentro desse panorama que passamos a tratar os processos de transmidiação da narrativa televisiva no Brasil, partindo das pesquisas realizadas e publicadas nos Anuários entre 2010 e 2015, sobretudo com foco nas estratégias metodológicas de sua análise.

\section{O tema da recepção transmídia: protocolos metodológicos}

Num sentido amplo e, ao mesmo tempo, específico, a incorporação no programa de estudos do Obitel do tema da recepção transmídia teve como objetivo central contribuir para atualizar e modernizar a linhagem latino-americana da pesquisa de recepção, deslocando-a para o espaço digital. Foi também uma maneira exequível de trabalhar a recepção dentro do protocolo metodológico unificado para 12 países de realidades muito distintas, ajustando-a ao monitoramento digital em substituição à pesquisa de campo. Esse foi o modo encontrado pelo Obitel para avançar na pesquisa de recepção fornecendo dados e análises sobre o que a recepção faz no ambiente das redes.

No Brasil, a televisão possui um amplo histórico de entrecruzamento de suas narrativas ficcionais, iniciado na década de 1960, com a produção de trilhas sonoras específicas

2 Para mais informações sobre o Observatório Ibero-americano de Ficção Televisiva e seus anuários, consultar: http://Obitel.net

3 Sobre a rede Obitel Brasil, consultar: http://obitelbrasil.blogspot.com.br/

4 Especialmente autores dos capítulos dos 5 livros da Coleção Teledramaturgia (2009, 2011,2013,2015,2017), como Lopes, Baccega, Jacks, Ronsini, Borges, Jacob, Pucci, Fechine, Greco, Massarolo, Sacramento, entre outros. 
de telenovelas, com o cinema nacional, e com livros, em que se (re)contam as histórias narradas na televisão. Com o tempo, as plataformas digitais passaram a ser utilizadas não apenas para reproduzir aspectos apresentados na tela, mas para criar, apresentar novos olhares e passar a explorar detalhes da produção (figurino, cenários, objetos de cena), preparação do elenco ou comentários do diretor, assim como os extras disponibilizados nas versões em DVD.

As emissoras brasileiras habitualmente produzem páginas na internet exclusivas para cada uma das telenovelas e séries, com variações quanto ao formato técnico e aos dispositivos de interatividade. Há conteúdos estáticos, como sinopses e matérias sobre bastidores da produção, e conteúdos interativos, como videogames e blogs, além da disponibilização, em alguns casos, dos capítulos na íntegra (com livre acesso ou para assinantes). Os perfis e blogs de autores de ficção são outro fenômeno que, além de populares, desfizeram a possível resistência por comentarem abertamente a trama em elaboração, aspectos da linguagem usada, a lógica da construção de personagens e até mesmo admitirem a incorporação das observações feitas pelos fãs nas tramas.

Para analisar as alterações nos processos de produção e recepção para e na internet, houve importantes avanços metodológicos nas pesquisas realizadas pelo Obitel desde 2010. Partindo da necessidade de métodos específicos de análise dos CGU (Conteúdo Gerado pelo Usuário), bem como das práticas das audiências na internet e seus níveis de engajamento (EVANS, 2011), as pesquisas do Obitel passaram a explorar uma variedade de métodos para analisar as relações dos fãs com as telenovelas e outros formatos de ficção televisiva.

Essa exploração metodológica teve início em 2010, quando os pesquisadores da rede começaram a se aprofundar na temática, debruçando-se sobre os conceitos citados no início deste artigo em suas interfaces com a ficção televisiva. Nesse momento, a revisão da literatura considerou principalmente os autores estrangeiros, uma vez que a bibliografia nacional era escassa e insatisfatória - diferentemente da atualidade. Foram lançadas as bases para a realização sequencial dos estudos de recepção transmídia, que inicialmente foi o Tema do $A n o^{5}$ do anuário 2010 e, a partir do ano seguinte, tornou-se um tópico fixo de pesquisa nos anuários do Observatório, permanecendo assim até o momento.

Os protocolos metodológicos desenvolvidos a partir de 2010 traziam diretrizes comuns para a observação e análise da recepção transmídia a serem elaboradas pelos países integrantes da rede. O olhar longitudinal nos permite entender os processos envolvidos de forma mais clara. Inicialmente, os grupos tiveram que tomar conhecimento acerca dos conceitos envolvidos e, a seguir, refletir e desenvolver coletivamente métodos de análise que se adequassem às realidades de cada país. Anualmente, o protocolo metodológico

5 O Tema do Ano é um dos tópicos permanentes da estrutura do anuário Obitel, em que um assunto ou objeto importante para os estudos de comunicação, geralmente emergente, é selecionado pela equipe do Obitel para receber o enfoque interdisciplinar e multicultural que marca a diversidade dos grupos de pesquisa dos 12 países que o integram. 
do Obitel como um todo é adaptado conforme as mudanças no contexto audiovisual, no entanto, é interessante perceber que o tema da recepção transmídia foi o que mais sofreu alterações ao longo dos anos. Isso ocorre, conforme apontamos, em virtude da natureza volátil do objeto estudado - as formas de transmidiação na recepção.

A primeira proposta metodológica, de 2011, teve como objetivo geral explorar o que ocorre nas práticas de recepção por meio de sites, blogs e plataformas das diversas ficções emitidas durante o ano, uma vez que elementos constituem operações transmídia realizadas pela produção com o intuito de estender o conteúdo de uma narrativa. Como objetivo específico, pretendia-se acompanhar, na internet, um título de ficção que tivesse estreado no ano em questão, selecionado com a intenção de: 1) analisar de que maneira essa ficção está construindo novos canais de recepção; 2) observar como as audiências interagem nesses canais ao deixar comentários e opiniões a respeito da ficção em questão ou a respeito dos comentários de outros usuários e 3) comparar as formas de interação entre as audiências. A seleção do corpus de análise também se baseava em um mesmo critério inicial - deveria ser feita dentro dos 10 títulos com maior audiência no ano e atender a um dos critérios seguintes: 1) a ficção que ocupou o primeiro lugar ou 2) aquela que obteve a maior repercussão na internet. Também o período de observação foi estabelecido: a última semana de exibição da ficção selecionada. Assim é que a recepção transmídia foi vista por meio da interação e participação das audiências em sites, blogs e outras plataformas oficiais das emissoras.

Essas estratégias metodológicas foram pensadas visando a analisar em que ponto se encontravam os processos de recepção interativa e participativa da ficção televisiva nos países ibero-americanos. Para esse fim, criou-se uma tipologia de níveis de interatividade com base em um continuum que cobria graus mínimos a máximos de engajamento, a saber: 1) Interatividade passiva: o usuário consome os conteúdos sem dar feedback. Utiliza os links, navega pelas páginas de forma silenciosa sem fazer notar sua presença. A interação é apenas reativa quanto ao conteúdo; 2) Interatividade ativa: o usuário responde a um estímulo dado apenas dentro das próprias condições oferecidas pelo emissor, por exemplo, a participação em alguma enquete. A interação é propositiva ou crítica quanto ao conteúdo; 3) Interatividade criativa: o usuário transforma-se em produtor de conteúdos, criando algo novo a partir daquilo que the foi dado. Estimulado pelo produtor original dos conteúdos a emitir alguma resposta, ele produz, superando sua condição de receptor e alcançando o grau de produtor (LOPES et al., 2009b).

Em 2012, a segunda proposta levou a um aperfeiçoamento do protocolo para além dos três níveis de interatividade com o intuito de passar a definir quais são os tipos de interação possibilitadas pelas plataformas em análise. Por exemplo, os sites foram classificados quanto ao seu tipo de interatividade: 1) Interativo (pode-se comentar e descarregar conteúdos); 2) Interativo em tempo real (interação com as audiências durante a exibição da ficção); 3) Visionado (pode-se aceder a conteúdos, mas não é permitido 
comentar); 4) Visionado interativo (comentários em tempo real, com outros visitantes); 5) Visionado interativo em rede (é possível assistir, comentar e compartilhar nas redes sociais); 6) Visionado transmídia (as mesmas funcionalidades dos demais, mas com oferta de conteúdo exclusivos). Para a análise específica dos comentários publicados pelas audiências nas plataformas digitais (sites e páginas nas redes sociais), também foi criada uma classificação desses comentários baseada nas funções da linguagem de Jakobson (2008) - emotiva, conotativa, referencial, metalinguística, fática e poética.

Após três anos de análises, os pesquisadores já conheciam o objeto empírico o suficiente para definir quais eram as práticas dominantes das audiências - modos produtivos pelos quais os usuários dão sentido aos objetos e representações das ficções -, que foram determinadas em 2013 como: comentar, interpretar, remixar, parodiar, criticar, escolher armazenar, compartilhar e discutir.

Nos anos de 2014 e 2015, a renovação da bibliografia utilizada revelou-se fundamental, pois notou-se o crescimento dos espaços de interação e participação criados pelas audiências e não mais apenas pelos produtores. Assim, voltou-se para a investigação das redes sociais mais usadas pelos fãs, como: grupos de discussão, grupos de WhatsApp, reddit, Facebook, perfis de personagens feitos por fãs, canais no YouTube, etc. A ideia de um monitoramento anual dessas redes foi aprovada e as equipes de pesquisa nacionais se tornaram mais autônomas para selecionar e analisar as plataformas digitais mais influentes em seus contextos audiovisuais.

\section{A recepção transmídia entre 2010 e 2015}

A seguir apontamos as principais análises que foram realizadas sobre a recepção transmídia nos Anuários de 2010 a 2015.

A pesquisa da equipe do Brasil no Anuário Obitel $2010^{6}$ destacou um exemplo que alcançou uma grande resposta do público, o blog da autora Glória Perez, em que se iniciam as discussões de sua novela Caminho das Índias, mesmo antes da estreia. A antecipação de temas que iriam ser tratados na telenovela provocou a participação ativa dos fãs (BOOTH, 2010) no processo mesmo de criação da trama. Para a Globo, 2009 foi um ano importante, pois o avanço da tecnologia digital passou a permitir que os programas fossem vistos mesmo quando os usuários estivessem em trânsito, em notebooks, telefones celulares e até o visionamento em transportes públicos, como ônibus e metrô. A emissora passa a investir em produtos ficcionais multiplataformas, com base no conceito de programação multimídia, ou seja, programas pensados não apenas para a TV, mas também para internet e celular. A soap opera Malhação, além de desenvolver blogs dos personagens ${ }^{7}$, aparece também no formato websérie com capítulos de até dois minutos criados com exclusividade

6 As análises realizadas pelo Obitel referem-se aos anos imediatamente anteriores ao da publicação.

7 Tramas da Globo com blogs de personagens nesse ano: Ger@l.com, Malhação, Três irmãs e Aline. E Isa TKM, exibida pela Band. 
para a internet. A minissérie Som \& fúria foi inicialmente produzida para a televisão, teve uma versão reduzida como filme e, pouco depois, foi lançada em box de DVDs. A série Norma (2009) foi uma experiência de programa ficcional interativo, na qual a personagem principal contava com a ajuda da plateia e de internautas para a construção do enredo. Páginas oficiais das novelas da faixa das $21 \mathrm{~h}$, como Caminho das Índias e Viver a Vida, incorporaram diversos blogs de personagens, além de opções de interatividade criativa por parte do internauta como produções de vídeos ${ }^{8}$.

No Anuário 2011, um estudo piloto/exploratório sobre fãs de ficção (HARRINGTON e BIELBY, 1995) lançou as bases de uma categorização desses fãs, ou seja, de uma tipologia definida conforme o nível de engajamento e participação dessas audiências. Uma extensa bibliografia internacional sobre fãs (HILLS, 2003; SANDVOSS, 2005; BOOTH, 2010; EVANS, 2011) colaborou no processo de desenvolvimento metodológico. Uma pirâmide ${ }^{9}$ ilustrou tal disposição, cuja base é constituída pela grande maioria dos fãs que aparecem divididos em duas faixas: espectadores e compartilhadores com baixo grau de participação (apenas assistem, leem, ouvem ou divulgam). Na terceira faixa, acima, encontram-se os comentadores, cuja participação nas redes ocorre por meio de comentários e avaliações. As duas últimas faixas são preenchidas pelos produtores, que publicam nas redes, criam e mantêm páginas como sites e/ou blogs, e pelos curadores, que editam, realizam moderações e possuem grande influência nas mídias sociais.

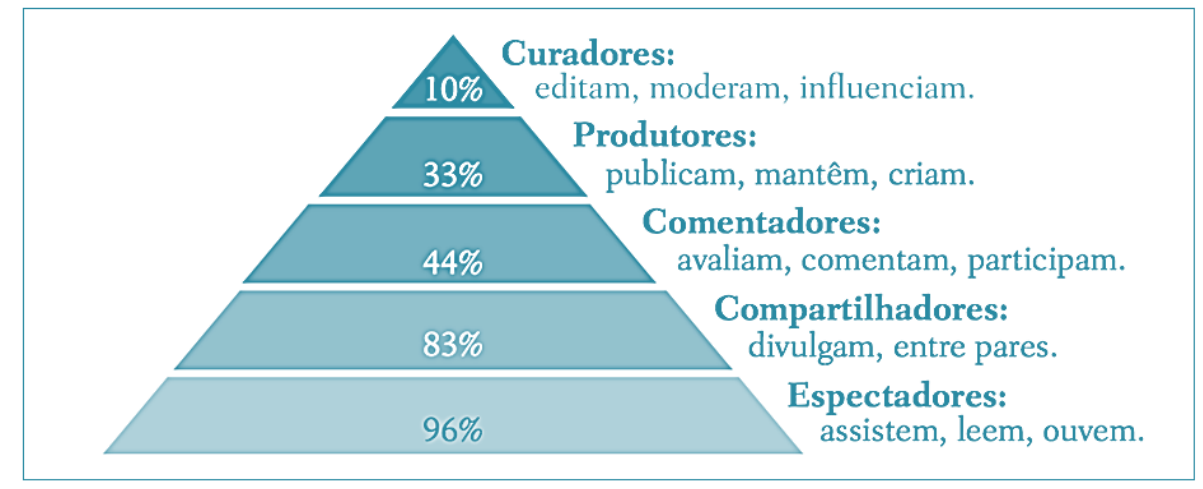

Fig.1. Tipologia de fãs da ficção televisiva no Brasil.

Fonte: Obitel, 2011.

O espalhamento dos conteúdos da telenovela Passione (GLOBO, 2009) em diversas plataformas foi analisado à luz dessa tipologia. Os resultados demonstraram claramente o fluxo e a efemeridade do que circula na rede, sobretudo no Twitter. Passione foi considerada um caso bem-sucedido de audiência ativa e criativa com várias ações transmídia, ao mesmo tempo que demonstrou aspectos de uma cultura participativa com

8 Todas as ficções citadas são da Globo, de 2009.

9 A tipologia foi sendo aperfeiçoada ao longo dos anos e atualmente é utilizada como referência nos estudos sobre fãs dos pesquisadores do Obitel. 
diversas modalidades de participação. Foi possível observar manifestações de audiência ativa e criativa que, embora ainda naquela época, representada por uma minoria, passou depois a ser considerada a principal fonte de espalhamento de assuntos ficcionais na internet.

De maneira semelhante, em 2012, outro estudo de caráter exploratório classificou as práticas interativas dos fãs em categorias que consideravam o nível de engajamento das mensagens publicadas nas redes. Os comentários dos fãs publicados no Facebook durante a última semana de exibição de Cordel Encantado (GLOBO, 2011), um dos títulos de ficção mais assistidos daquele ano, tiveram como assuntos centrais a história e os personagens.

Em 2013, o Anuário voltou-se para análise da telenovela Avenida Brasil (GLOBO, 2012), que marcou história por reconquistar um grande público para o horário nobre da televisão. A intensidade do espalhamento da discussão sobre Avenida Brasil nas redes auxiliou no processo de viralização dos assuntos tratados por essa novela. A maneira como reuniu novamente os brasileiros em frente à TV e nas redes fez com que atingisse estatuto de uma media event (evento midiático) pela comoção e mobilização alcançadas, atualizando a noção de telenovela como narrativa da nação (LOPES, 2009a). Práticas sociais que então eram novidades, como as conversações sobre a ficção nas redes em simultâneo à audiência da ficção na TV, chegaram a reunir meio milhão de fãs só na página oficial da novela no Facebook.

As pesquisas do Anuário 2014 demonstraram a consolidação do hábito de acompanhar a programação da TV em múltiplas telas. O público elegeu o Twitter e o Facebook como as redes favoritas, onde expressou um alto índice de engajamento por meio de produções tanto textuais quanto imagéticas. Também a partir desse ano, a Globo lançou a estratégia de concentrar a divulgação de todas as suas ficções numa única página do Facebook - Gshow - substituindo as páginas individuais de cada título.

A acumulação de capital simbólico (BOURDIEU, 2013) por parte dos fãs curadores (aqueles que criam conteúdos, moderam e influenciam outros fãs) mostrou-se evidente sobretudo na página Félix Bicha Má10, criada por um fã no Facebook no dia seguinte à estreia da telenovela Amor à Vida (GLOBO, 2013). Essa figura narrativa da autonomia da personagem (REIS, 2015; RYAN, 2018) passa a ganhar destaque nos CGU dos fãs de telenovela, evidenciando o prazer em cultuar os personagens de seu interesse.

As interações no espaço digital paralelas à audiência das novelas na TV se consolidam como prática cultural em múltiplas telas, com destaque para o celular como principal dispositivo de acesso. A adoção de estratégias transmídia na recepção dos conteúdos televisivos, tanto pelos fãs, como pelas emissoras, continuou a superar as expectativas e a suscitar a participação e a criatividade das audiências, conforme destacaram as últimas pesquisas do Obitel.

10 Referente ao personagem Félix, um vilão homossexual que ganhou a simpatia do público pelo tom de sarcasmo que acompanhava suas falas. 


\section{Ao modo de conclusão}

Acreditamos que um trabalho como este, que teve o propósito de revisitar algumas teorias e métodos que fundamentaram as pesquisas de diversos grupos no Brasil e na Ibero-América dentro do projeto do Obitel, abre espaço para novas questões. Como será a produção de narrativas transmídia no futuro, que nascem com a intenção de espalhar o conteúdo ficcional pelas diversas mídias, dando atenção às novas formas de circulação desses conteúdos, construindo universos transmídia (JENKINS, 2008; EVANS 2011; SCOLARI, 2013; RYAN, 2018)? Esses universos narrativos envolverão quais lógicas de produção e consumo? Quais serão os novos espaços de comunicação e socialização?

Mostramos que a partir principalmente da literatura internacional, os pesquisadores da rede Obitel Brasil (braço nacional do Obitel) desenvolveram formas adaptadas e também originais de análise ao contexto brasileiro da ficção televisiva. Mais ainda, trabalharam termos conexos como TV Social, especialmente no caso dos grupos de pesquisa de Fechine e de Borges, de Jacks e de Ronsini ${ }^{11}$, que têm abordado o lugar da recepção no ambiente da cultura participativa e revelado aspectos da centralidade do sujeito como produtor de sentido, apenas para citar alguns exemplos presentes nos estudos mencionados anteriormente, publicados na Coleção Teledramaturgia.

Ao realizarmos essa análise longitudinal, percebemos nas pesquisas realizadas pelo Obitel entre 2010 e 2015, que a recepção transmídia constitui uma importante temática nos renovados estudos televisivos em geral e da ficção televisiva em particular. O grau de engajamento das audiências tem crescido com a partilha de conteúdos e com a criação de comunidades online de fãs (BOOTH, 2010), tornando a internet um espaço privilegiado para o estudo das culturas de fãs de telenovela.

No âmbito empírico, notamos a utilização do cruzamento de múltiplas metodologias no esforço contínuo de compreender o fenômeno de aproximação da ficção televisiva tradicional ao modelo de narrativa transmídia. Percebemos que a circulação em diferentes suportes e plataformas inclui, de alguma forma, uma reconfiguração da matriz cultural melodramática (MARTíN-BARBERO, 2001), como mencionamos no Anuário Obitel 2017. De forma complementar, observamos que as audiências acompanharam o novo paradigma marcado pela convivência da cultura analógica com a digital, assistindo à TV em múltiplas plataformas, de maneira coletivamente socializada e, por isso, fundamentando a ideia de crescimento das audiências de ficção televisiva, justificando o estudo dos fãs (LOPES, 2017).

11 Todas as autoras citadas possuem pesquisas publicadas nos livros da Coleção Teledramaturgia. 
da Comunicação da USP (CECOM). É criadora e coordenadora da rede internacional de pesquisa OBITEL (Observatório Ibero-Americano da Ficção Televisiva) e da rede nacional de pesquisa OBITEL-BRASIL. É pesquisadora $1 \mathrm{~A}$ do CNPq.

immaco@usp.br

Fernanda Castilho é pós-doutora pela ECA-USP e professora do Centro Estadual de Educação Tecnológica Paula Souza (Fatec). É doutora e mestre pela Universidade de Coimbra (Portugal). É pesquisadora do Centro de Estudos de Telenovela da ECA-USP (CETVN) e do Observatório Iberoamericano de Ficção Televisiva OBITEL.

fernandacasty@gmail.com

\section{Referências}

BOOTH, P. Digital fandom: New media studies. New York: Peter Lang, 2010.

BOURDIEU, P. Capital simbólico e classes sociais. Novos Estudos CEBRAP, 2013, pp. 105-115.

CASTELLS, M. Communication power. New York: Oxford University Press, 2009.

EVANS, E. Transmedia television: Audiences, new media, and daily life. Londres: Taylor \& Francis, 2011.

FECHINE, Y. Transmediação na produção ficcional do núcleo Guel Arraes: a lógica da familiaridade em novas formas culturais. Anais do XVIII Encontro da Compós. Belo Horizonte, junho de 2009.

GARCÍA CANCLINI, N. Leitores, espectadores e internautas. São Paulo: lluminuras, 2008.

HARRINGTON, C. L.; BIELBY, D. Soap fans: Pursuing pleasure and making meaning in everyday life. Philadelphia: Temple University Press, 1995.

HILLS, M. Fan cultures. Londres: Routledge, 2003.

JAKOBSON, R. Linguística e comunicação. Editora Cultrix, 2008.

JENKINS, H. The cultural logic of media convergence. International Journal of Cultural Studies, v.7, n.1, 2004.

Cultura da convergência. São Paulo: Aleph, 2008.

Textual poachers: Television fans and participatory culture. Routledge, 2012.

LÉVY, P. As tecnologias da inteligência. São Paulo: Editora 34, 1993.

Cibercultura. São Paulo: Editora 34, 1999.

A inteligência coletiva. Por uma antropologia do espaço. São Paulo: Loyola, 2003.

LOPES, M.I.V. Telenovela brasileira: uma narrativa sobre a nação. Comunicação \& Educação, v.26, jan/abr, 2003.

Telenovela como recurso comunicativo. MATRIZes, v. 3, n.1, pp. 21-47, dez./ago, 2009a. 
et al. Transmediação, plataformas múltiplas, colaboratividade e criatividade na ficção televisiva brasileira. In: LOPES, M.I.V. et al (Org.). Ficção Televisiva no Brasil: temas e perspectivas. São Paulo: Ed. Globo, 2009b.

LOPES, M.I.V. (org.). Ficção Televisiva no Brasil: temas e perspectivas. Coleção Teledramaturgia, v.1. São Paulo: Globo, 2009.

(org.). Ficção televisiva transmidiática no Brasil: plataformas, convergência, comunidades virtuais. Coleção Teledramaturgia, v.2. Porto Alegre: Sulina/Globo, 2011.

(org.). Estratégias de Transmidiação na Ficção Televisiva Brasileira. Coleção Teledramaturgia, v.3. Porto Alegre: Sulina/Globo, 2013.

(org.). Por uma Teoria de Fãs da Ficção Televisiva Brasileira. Coleção Teledramaturgia, v.4. Porto Alegre: Sulina/Globo, 2015.

(org.). Por uma Teoria de Fãs da Ficção Televisiva Brasileira II - Práticas de fãs no ambiente da cultura participativa. Coleção Teledramaturgia, v.5. Porto Alegre: Sulina/Globo, 2017.

MARTíN-BARBERO, J. Cidade virtual: novos cenários da comunicação. Comunicação \& Educação, v.4, n.11, pp.53-67, jan/abr, 1998.

Dos meios às mediações. Rio de Janeiro: Ed. UFRJ, 2001.

Ofício de cartógrafo - travessias latino-americanas da comunicação e da cultura. São Paulo: Loyola, 2004.

MELUCCI, A. Asumir un compromiso: identidad y movilización en los movimientos sociales. Zona abierta, n.69, pp.153-180, 1994.

OROZCO GÓMEZ, G. Entre pantallas: nuevos roles comunicativos de las audiencias. In: Díaz, M. A. et al. (coord.). Pensar lo contemporáneo: de la cultura situada a la convergencia tecnológica, Barcelona: Anthropos, 2009, pp.287-296.

PRENSKY, M. Nativos digitais, imigrantes digitais. On the horizon, v.9, n.5, pp. 1-6, 2001.

PRIMO, A. Interação mediada por computador: comunicação, cibercultura, cognição. Porto Alegre: Sulina, 2007.

REIS, C. Pessoas de livro: estudos sobre a personagem. Imprensa da Universidade de Coimbra/ Coimbra University Press, 2015.

RYAN, M.L. Narratologia transmedia e transmedia storytelling. Mediapolis. Revista de Comunicação, Jornalismo e Espaço Público, 2018, n.6, pp. 9-25.

SANDVOSS, C. Fans: The mirror of consumption. Cambridge: Polity Press, 2005.

SCOLARI, C. Hacer clic - Hacia una sociosemiotica de las interacciones digitales. Barcelona: Gedisa, 2004. 